\title{
KADAR NATRIUM SERUM PADA LATIHAN FISIK INTENSITAS RINGAN MAHASISWA FAKULTAS KEDOKTERAN UNIVERSITAS SAM RATULANGI
}

\author{
Tifany S. Lesar \\ Youla A. Assa \\ Diana S. Purwanto \\ Bagian Biokimia Fakultas Kedokteran Unversitas Sam Ratulangi Manado \\ Email: tifany.shanon@yahoo.com
}

\begin{abstract}
Sodium is the most abundant cation in extracellular fluids that creates much of osmotic pressure to maintain intravascular and interstitial volume to protect the body from excessive fluid loss and it is the highest concentration of electrolytes that carried out of the body through sweat. This study aimed to detect changes in sodium levels before and after light intensity exercise in the students year 2010 Faculty of Medicine Sam Ratulangi University. This study was a preexperimental with one group pretest \& posttest design. The respondents on this study were 19-22 years, consisting of 18 men and 12 women. Data was collected by determining the serum sodium levels before and after 30 minutes light intensity physical exercise on treadmill. Sodium levels before physical exercise were $140.70 \pm 2.231$ and after physical exercise were $141.80 \pm 1.750$. Statistical test results showed there were significant differences in serum sodium levels before and after light intensity exercise ( $\mathrm{p}=0.001)$. It can be concluded there is an effect of light intensity physical exercise in serum sodium levels in the students year 2010 Faculty of Medicine Sam Ratulangi University.
\end{abstract}

Keywords: sodium, physical exercise, light intensity.

\begin{abstract}
Abstrak: Natrium merupakan kation terbanyak cairan ekstrasel yang secara osmotik bertanggung jawab mempertahankan volume intravaskular dan interstisial untuk melindungi tubuh terhadap kehilangan cairan yang berlebihan dan natrium merupakan elektrolit dengan konsentrasi tertinggi yang terbawa keluar tubuh melalui keringat. Penelitian ini bertujuan untuk mengetahui perbandingan kadar natrium serum sebelum dan sesudah latihan fisik intensitas ringan pada mahasiswa Fakultas Kedokteran Universitas Sam Ratulangi angkatan 2010. Penelitian ini merupakan penelitian pra-eksperimental one group pretest \& posttest design. Responden dari penelitian ini berusia 19-22 tahun terdiri dari 18 laki-laki dan 12 perempuan. Data diperoleh melalui pemeriksaan laboratorium yaitu kadar natrium serum sebelum dan sesudah latihan fisik intensitas ringan selama 30 menit berjalan di atas treadmill. Rata-rata kadar natrium sebelum latihan fisik adalah $140.70 \pm 2.231$ dan sesudah latihan fisik adalah $141.80 \pm 1.750$. Hasil penelitian menunjukkan terdapat perbedaan signifikan kadar natrium serum sebelum dan sesudah
\end{abstract}


latihan fisik intensitas ringan ( $\mathrm{p}=0.001$ ). Berdasarkan hasil penelitian dapat disimpulkan bahwa terdapat pengaruh latihan fisik intensitas ringan terhadap kadar natrium serum mahasiswa Fakultas Kedokteran Universitas Sam Ratulangi angkatan 2010.

Kata Kunci: natrium, latihan fisik, intensitas ringan.

Studi World Health Organization (WHO) menyatakan bahwa gaya hidup duduk terus menerus dalam bekerja adalah 1 dari 10 penyebab kematian dan kecacatan di dunia. Lebih dari dua juta kematian setiap tahun disebabkan oleh kurangnya bergerak/aktifitas fisik dan pada kebanyakan negara di seluruh dunia, 60\% hingga 85\% orang dewasa tidak melakukan aktivitas fisik yang cukup. ${ }^{1}$

Latihan fisik (exercise) didefinisikan sebagai subkelompok aktivitas fisik berupa gerakan tubuh yang terencana, terstruktur, dan repetitif (berulang) untuk memperbaiki atau memelihara kebugaran fisik. Aktifitas fisik dapat dinilai berdasarkan tipe, frekuensi, durasi dan intensitas. ${ }^{2}$ Pada latihan fisik intensitas ringan, denyut nadi dipertahankan antara 50-63\% dari denyut nadi maksimal. ${ }^{3}$

Saat berolahraga atau latihan fisik, terjadi peningkatan jumlah keringat sebagai mekanisme tubuh untuk membantu mempertahankan suhu tubuh selama periode penambahan panas berlebihan. ${ }^{4}$ Laju pengeluaran keringat seseorang bervariasi, bergantung pada kondisi lingkungan, intensitas latihan, tingkat kebugaran, asupan cairan, dan juga berbeda pada orang yang sudah teraklimatisasi. ${ }^{5}$ Kehilangan keringat yang cukup banyak dapat mengurangi kinerja seseorang secara bermakna, dan jika mencapai 5-10\% penurunan berat badan dapat berakibat serius dan dapat menyebabkan dehidrasi, kram otot, mual dan efek lainnya. ${ }^{6}$

Natrium, kalium, dan klorida merupakan tiga mineral utama yang terdapat dalam komposisi air keringat. Semakin besar laju pengeluaran keringat, maka laju kehilangan natrium, kalium, dan klorida dalam tubuh akan semakin besar. ${ }^{7}$

Pada saat melakukan latihan fisik, dapat terjadi perubahan nilai kadar natrium dalam tubuh. Hazar et al ${ }^{8}$ dalam penelitiannya terhadap pemain bola kaki menemukan bahwa tidak terdapat perbedaan yang signifikan pada kadar elektrolit, demikian juga pada penelitian Koc ${ }^{9}$ pada pemain bola tangan menyebutkan terjadi penurunan kadar natrium sesudah pertandingan namun tidak menunjukkan perubahan yang bermakna. Lain halnya dengan Sprenger ${ }^{5}$, pada penelitiannya pada pemain ice hockey, ia mendapatkan perubahan kadar natrium yang signifikan sesudah permainan dan 33\% dari pemain tersebut mengalami dehidrasi ringan.

Berdasarkan uraian tersebut di atas, penulis tertarik untuk meneliti perbandingan kadar natrium serum sebelum dan sesudah latihan fisik intensitas ringan pada mahasiswa Fakultas Kedokteran Universitas Sam Ratulangi angakatan 2010.

\section{METODE PENELITIAN}

Penelitian ini merupakan penelitian pra-eksperimental dengan rancangan one group pretest and posttest. Penelitian dilaksanakan di tempat fitness dan pemeriksaan darah dilaksanakan di 
laboratorium. Populasi pada penelitian ini adalah mahasiswa Fakultas Kedokteran Universitas Sam Ratulangi Angkatan 2010 yang berjumlah 282 orang. Sampel berjumlah 30 orang. Sampel didapatkan melalui purposive sampling. Penelitian latihan fisik intensitas ringan dilakukan dengan berjalan di atas treadmill selama 30 menit dengan target denyut jantung selama latihan antara 50-63\% dari denyut nadi maksimum (DNM). ${ }^{3}$ Denyut nadi maksimum diperoleh dari 200 umur responden. ${ }^{8}$

Data primer didapatkan dari pemeriksaan laboratorium kadar natrium serum dengan metode ISE (Ion Selective Electrode). Data diolah dengan menggunakan SPSS dengan analisa univariat dan bivariat menggunakan uji t berpasangan (paired t-test).

\section{HASIL PENELITIAN}

Penelitian ini terdapat 30 responden yang terdiri dari 18 responden berjenis kelamin lakilaki (60\%), dan 12 responden berjenis kelamin perempuan (40\%) (Tabel 1). Seluruh responden dalam penelitian ini memiliki kadar natrium yang normal (135-145 mEq/L) baik sebelum melakukan latihan fisik intensitas ringan, maupun sesudah melakukan latihan fisik.

Tabel 1. Distribusi responden berdasarkan jenis kelamin

\begin{tabular}{ccc}
\hline Jenis Kelamin & Jumlah & Persentase \\
\hline Laki-laki & 18 & 60 \\
Perempuan & 12 & 40 \\
Total & 30 & 100 \\
\hline
\end{tabular}

Hasil penelitian terhadap 30 responden ini didapatkan 26 responden mengalami perubahan kadar natrium sesudah latihan fisik intensitas ringan. 20 diantaranya (66.7\%) mengalami peningkatan kadar natrium, 6 diantaranya (20\%) mengalami penurunan kadar natrium, sedangkan 4 responden lainnya (13.3\%) tidak mengalami perubahan kadar natrium (Tabel 2).

Tabel 2. Distribusi responden berdasarkan perubahan kadar natrium serum

\begin{tabular}{ccc}
\hline & Jumlah & Persentase \\
\hline Meningkat & 20 & 66.7 \\
Tidak Berubah & 4 & 13.3 \\
Menurun & 6 & 20 \\
\hline
\end{tabular}

Rata-rata kadar natrium serum sebelum latihan fisik $140.70 \mathrm{mEq} / \mathrm{L}$, dengan median $141.00 \mathrm{mEq} / \mathrm{L}$; standar devisasi 2.231; nilai terbanyak (mode) 141. Kadar natrium terendah yang didapat sebelum latihan fisik adalah $137 \mathrm{mEq} / \mathrm{L}$ dan yang tertinggi $145 \mathrm{mEq} / \mathrm{L}$, sedangkan sesudah latihan fisik intensitas ringan rata-rata kadar natrium $141.80 \mathrm{mEq} / \mathrm{L}$, median 142.00 $\mathrm{mEq} / \mathrm{L}$, dengan standar deviasi 1.750; nilai terbanyak (mode) 142. Kadar natrium terendah sesudah latihan fisik yang didapatkan adalah $138 \mathrm{mEq} / \mathrm{L}$ dan yang tertinggi $145 \mathrm{mEq} / \mathrm{L}$. 
Tabel 3. Data statistik responden sebelum dan sesudah latihan fisik intensitas ringan

\begin{tabular}{ccc}
\hline & Sebelum Latihan Fisik & Sesudah Latihan Fisik \\
\hline Mean & 140.70 & 141.80 \\
Median & 141.00 & 142.00 \\
Mode & 141 & 142 \\
Std. Deviation & 2.231 & 1.750 \\
Minimum & 137 & 138 \\
Maximum & 145 & 145 \\
\hline
\end{tabular}

Data dalam penelitian ini diuji dengan menggunakan uji t berpasangan (paired t-test). Tabel 4 menunjukkan nilai korelasi sebesar 0.0664 dengan signifikansi 0.000 . Ini berarti terdapat hubungan antara latihan fisik intensitas ringan dengan kadar natrium.

Tabel 4. Paired Samples Correlations

\begin{tabular}{cccc}
\hline & $\mathbf{N}$ & Correlation & Sig. \\
\hline Sebelum \& Sesudah & 30 & .664 & .000 \\
\hline
\end{tabular}

Hasil paired samples tests menunjukkan nilai t hitung yang didapat dari output adalah 3.568, dan nilai signifikansinya 0.001 (Tabel 5). Hal ini menunjukkan bahwa terdapat perbedaan kadar natrium yang signifikan sebelum dan sesudah latihan fisik intensitas ringan pada mahasiswa Fakultas Kedokteran Universitas Sam Ratulangi angkatan 2010.

Tabel 5. Paired Samples Tests

\begin{tabular}{cccccc}
\hline Mean & Std. Deviation & $\begin{array}{c}\text { Std. Error } \\
\text { Mean }\end{array}$ & $\mathbf{t}$ & df & Sig. (2-tailed) \\
\hline-1.100 & 1.689 & .308 & -3.568 & 29 & .001 \\
\hline
\end{tabular}

\section{BAHASAN}

Hasil penelitian kadar natrium serum pada mahasiswa Fakultas Kedokteran Universitas Sam Ratulangi angkatan 2010 didapatkan data seluruh responden dalam penelitian memiliki kadar natrium yang normal sebelum melakukan latihan fisik maupun setelah melakukan latihan fisik. Sprenger ${ }^{5}$ pada penelitiannya terhadap pemain ice hockey, mendapatkan sebagian responden mengalami dehidrasi ringan setelah permainan.

Berbeda dengan penelitian yang dilakukan oleh Sprenger ${ }^{5}$, pada penelitian ini tidak terdapat responden yang mengalami hipernatremia maupun hiponatremia, hanya sebagian dari responden mengalami penurunan kadar natrium sesudah latihan fisik. Hasil penelitian ini sejalan dengan penelitian yang dilakukan oleh $\mathrm{Koc}^{9}$ yang respodennya mengalami sedikit penurunan kadar natrium sesudah bermain bola tangan, tetapi bedanya Koc melakukan penelitian pada atlet sedangkan penelitian ini dilakukan pada mahasiswa kedokteran. Penurunan ini disebabkan karena 
pengeluaran keringat saat latihan fisik menyebabkan natrium yang terkandung di dalamnya ikut terbawa keluar tubuh melalui keringat, sehingga semakin besar laju pengeluaran keringat, laju kehilangan natrium juga akan semakin besar. ${ }^{7}$ Orang yang melakukan latihan fisik di iklim yang bersuhu lebih tinggi akan lebih sering mengalami kehilangan cairan dan elektroit sehingga dapat mengalami dehidrasi dengan laju pengeluaran keringatnya dapat mencapai 1-2 liter/jam. ${ }^{10}$

Penelitian ini juga sejalan dengan penelitian yang dilakukan oleh Wahyudi et al $^{11}$ dalam penelitiannya terhadap anak Sekolah Lanjutan Tingkat Pertama (SLTP). Wahyudi juga melakukan uji latihan fisik dengan menggunakan treadmill dan hasilnya sebagian responden mengalami penurunan kadar natrium yang bermakna, tetapi bedanya, waktu latihan yang mereka gunakan hanya 10 menit. Responden pada penelitiannya juga diberi air putih 10 menit sebelum latihan fisik dilakukan, sedangkan pada penelitian ini, responden dipuasakan selama 3 jam sebelum pengukuran kadar natrium dan latihan fisik dilakukan.

Responden dalam penelitian ini sebagian besar banyak yang mengalami peningkatan kadar natrium. Peningkatan natrium ini dapat terjadi akibat defisit cairan tubuh karena pengeluaran keringat akibat ekskresi air yang jauh melebihi ekskresi natrium dan ditambah dengan asupan air yang kurang. ${ }^{12}$ Orang yang secara teratur melakukan latihan fisik dapat mengalami aklimatisasi atau adaptasi dalam tubuhnya. Adaptasi adalah perubahan struktur atau fungsi organ-organ tubuh yang sifatnya lebih menetap, karena mengikuti atau sebagai akibat dari latihan fisik yang diberikan secara teratur dalam periode waktu tertentu. Wiarto ${ }^{10}$ menyebutkan reaksi adaptasi hanya akan timbul apabila beban latihan yang diberikan intensitasnya cukup memadai dan berlangsung cukup lama. Siswantiningsih ${ }^{13}$ dalam penelitiannya juga menyebutkan bahwa orang yang sudah beraklimatisasi terhadap iklim panas dan sudah sering berkeringat dapat menyebabkan berkurangnya pengeluaran garam melalui keringat.

Peningkatan kadar natrium sesudah latihan fisik pada penelitian ini sejalan dengan hasil penelitian yang dilakukan oleh Wadud. Wadud ${ }^{14}$ dalam penelitiannya terhadap mahasiswa pendidikan olahraga, mendapatkan peningkatan kadar natrium setelah respondennya melakukan aktivitas fisik aerobik dan anaerobik. Bedanya, pada hasil uji statistik, hasil penelitiannya tidak menunjukkan peningkatan kadar natrium yang bermakna sesudah melakukan latihan aerobik, tetapi lain halnya dengan responden yang melakukan latihan anaerobik. Wadud menemukan perubahan kadar natrium yang bermakna dan sebagian besar respondennya mengalami hipernatremia.

Sebagian kecil responden tidak mengalami perubahan kadar natrium sebelum dan sesudah latihan fisik intensitas ringan. Hazar et al ${ }^{15}$ dalam penelitiannya terhadap pemain bola kaki juga tidak menemukan perbedaan kadar natrium yang signifikan sebelum dan sesudah permainan. Hasil penelitiannya menyebutkan waktu latihan masih kurang untuk membuat perubahan kadar elektrolit atau dehidrasi; dengan kata lain butuh waktu lebih lama agar kadar elektrolit sesudah latihan mengalami perubahan.

Keterbatasan penelitian ini antara lain kurangnya responden dalam penelitian. Keterbatasan lainnya dalam penelitian ini yaitu suhu ruangan pada tempat penelitian yang tidak stabil. Suhu ruangan yang tidak stabil dapat berpengaruh terhadap pengeluaran keringat, selain itu, pada penelitian ini tidak dilakukan penelitian tentang tinggi badan dan berat badan terhadap hubungannya dengan jumlah cairan tubuh total.

\section{SIMPULAN}

Berdasarkan hasil penelitian yang didapatkan, maka dapat disimpulkan bahwa terdapat perbedaan yang signifikan pada kadar natrium serum mahasiswa Fakultas Kedokteran 
Universitas Sam Ratulangi angkatan 2010 sebelum dan sesudah latihan fisik intensitas ringan. Kadar natrium serum responden seluruhnya adalah normal, baik sebelum maupun sesudah melakukan latihan fisik.

\section{DAFTAR PUSTAKA}

1. Departemen Kesehatan Republik Indonesia. Panduan kesehatan olahraga bagi petugas kesehatan [homepage on the internet]. 2002 [cited 2013 Sep 8]. Available from: http://www.depkes.go.id/downloads/Panduan\%20Kesehatan\%20Olahraga.pdf.

2. Sjostrom M, Ekelund U, Ynvge A. Pengkajian aktivitas fisik. In: Gibney MJ, Margetts BM, Kearney JM, Arab L, editors. Gizi kesehatan masyarakat. Hartono A, alih bahasa. Jakarta: EGC, 2009; p. 133-42.

3. American College of Sports Medicine. ACSM's guidelines for exercise testing and prescription. In: Thompson WR, Gordon NF, Pescatello LS, editors. Atlanta: Wolters Kluwer, 2009; p. 6.

4. Sherwood L. Keseimbangan cairan dan asam-basa. In: Fisiologi manusia dari sel ke sistem (Edisi 6). Pendit BU, alih bahasa. Jakarta: EGC, 2011; p. 605-39.

5. Sprenger HML. Fluid balance before and during exercise and the effects of exercise induced dehydration on physiological responses, substrate oxidation, muscle metabolism, and performance [PhD thesis]. Canada: Guelph University; 2011.

6. Guyton AC, Hall JE. Kompartemen cairan tubuh. In: Buku ajar fisiologi kedokteran (Edisi 11). Irawati, Ramadhani D, Indriyani F, Dany F, Nuryanto I, Rianti S, alih bahasa. Jakarta: EGC, 2008; p. 307-23.

7. Irawan MA. Cairan tubuh, elektrolit dan mineral [homepage on the internet]. 2007 [cited 2013 Sep 8]. Available from: http://www.pssplab.com/journal/01.pdf.

8. Engka JNA, Soempeno B, Suwono. Pengaruh penambahan intensitas latihan terhadap ambilan oksigen maksimum ( $\mathrm{VO}_{2}$ maks) kajian pada anggota klub jantung sehat. Majalah Sains Kesehatan. 2003;16(1):173-90.

9. Koc H. The effect of acute exercises on blood electrolyte values in handball players. Afr J Pharm Pharmacol. 2011;4(1):93-97.

10. Wiarto G. Fisiologi dan olahraga. Yogyakarta: Graha Ilmu, 2013; p. 153-75.

11. Wahyudi, Ginting S, Siregar C, Yoel C, Pasaribu S, Lubis M. Perubahan Kadar Natrium dan Kalium Serum Akibat Pemberian Glukosa 40\% pada Latihan Fisik Akut. Sari Pediatri. 2008;10(2):77-82.

12. Madjid AS, Hegar B, Nur BM, Rumende CM, Darwis $D$, Soewoto $H$, et al. Fisiologi keseimbangan air dan elektrolit. In: Darwis D, Moenadjat Y, Nur BM, Siregar P, editor. Gangguan keseimbangan air-elektrolit dan asam-basa, fisiologi, patofisiologi, diagnosis dan tatalaksana (Edisi 2). Jakarta: Balai Penerbit FK-UI, 2008; p. 29-114.

13. Siswantiningsih KA. Perbedaan denyut nadi sebelum dan sesudah bekerja pada iklim kerja panas di unit workshop pt. indo acidatama tbk kemiri, kebakkramat karanganyar $\left[\mathrm{D}_{3}\right.$ thesis]. Surakarta: Universitas Sebelas Maret; 2010.

14. Wadud MA. Pengaruh aktivitas aerobik dan anaerobik terhadap kadar anti diuretik hormon (ADH) dan elektrolit darah. Poltekkes Palembang Journal [serial on the internet]. 2012 [cited 2014 Jan 8]. Available from: http://poltekkespalembang.ac.id/userfiles/files/pengaruh_aktivitas_fisik_aerobik_good.pdf.

15. Hazar M, Sever O, Gurkan AC, Er FN, Erol M. Physiologic responses of macro elements to maximal aerobic exercise in male and female footballers. Life Sci J. 2013;10(6s):734-7. 